Finanse, Rynki Finansowe, Ubezpieczenia nr 5/2017 (89), cz. 1

\title{
Investment activity of local government units in the context of finance management
}

\author{
Małgorzata Dworakowska"
}

\begin{abstract}
Purpose - The article aims to present the specific characteristics of finance management in local government units in the context of implementation of investments by these entities. These reflections are envisaged with consideration given to the analysis of investment activity of local government units in Poland in the years 2007-2015.

Design/methodology/approach - Due to the multi-aspect research area a variety of research methods was used with a view to achieving the assumed objective. The research procedure involved non-reactive research methods, the method of analysis of official documents as well as the historical and comparative method.

Findings - The conducted analyses reveal specific characteristics of investment activity pursued by local government units and their special role from the perspective of finance management of these entities. The collected data testifies engagement of particular categories of local government units in Poland in the years 2007-2015 in the execution of capital expenditure financing the investments.

Originality/value - The analysis of the researched issue confirms that finance management is of considerable importance in local government units. It is especially significant in the context of substantial engagement in the execution of the investment. Investment activity of local government units depends on financial standing of these entities, which should be affected by efficient and effective management. The analysis of the structure of budget expenditure incurred by particular categories of local government units in Poland in the years 2007-2015 enables observation of differentiation in this respect and constitutes the grounds for evaluation of the intended purpose of expended funds.
\end{abstract}

Keywords: investment activity, local government units, finance management, capital expenditure

\section{Introduction}

Requirements of the management process should be taken into account in functioning of each organisation. The undertaken activities oriented on all types of an organisation's resources (in terms of finance, people, assets and information) should contribute to achieving the objective in an efficient and effective manner. Implementation and use of the elements of management process is typical not only of private entities as more and more interest in them can be observed among entities of the public sector including local government units.

An indispensable element of management in case of local government units is finance management. It involves multi-aspect dependencies related to management of limited financial resources when it is necessary to carry out public tasks with a view to meeting residents'

\footnotetext{
* PhD Małgorzata Dworakowska, Warsaw School of Economics, Collegium of Socio-Economics, al. Niepodległości 162,02-554 Warsaw, mdwora@sgh.waw.pl.
} 
collective needs. As far as management of finance of local government units is concerned it is budget expenditure that should be paid attention to, especially capital expenditure as it is a sign of investment activity on the part of these entities.

Investment activity of local government units depends on the state of their finance and is related to implementation of investment undertakings by these entities. The size of capital expenditure of local government units depends on the number, scope and complexity of the performed public tasks as well as the financial capacity of these entities. Management of limited financial resources needs working out solutions enabling indication of expenditure priorities as well as determination of the most important activities of investment nature.

Carrying out investments is extremely significant in each economy. They enable limitation of disproportions between better and worse developed areas of the state and determine opportunities of further development. Local government units in Poland are an important investor and their investments affect the local and regional development. Well thought through investment undertakings scheduled for implementation combined with taking into account their present and future financing necessary to maintain the constructed elements of infrastructure in appropriate condition are crucial activities in the undertaken and consciously implemented investment process.

The article aims to present the specific characteristics of finance management in local government units in the context of implementation of investments by these entities. These reflections are envisaged with consideration given to the analysis of investment activity of local government units in Poland in the years 2007-2015. As the scope of this research is limited the subject not to be analysed is the issues connected with availability and obtaining funds from external sources.

\section{Finance management in local government units}

Finance management of a local government unit means comprehensive management of financial resources which aims at (Jastrzębska, 2009, p. 72):

- fulfilment of the assumptions of financial policy involving selection of sources and methods of accumulating public money as well as tendencies and manners of its expenditure with a view to achieving the adopted objectives of economic and social nature,

- coordination of the implementation of financial policy,

- monitoring and verification of the use of financial resources and the effects of undertaken activities.

Finance management is a very important and multithreaded area of the analysis. In undertaken resolutions the authorities of local government units must remember about executing the tasks assigned to these entities and implementing activities with a view to meeting the collective needs of residents. Efficient and effective execution of these obligations needs expenditure and management of funds in a manner ensuring the interest of the self-government community. Thus, finance management directly affects the residents' quality of life. 
The essence of managing finance by a local government unit entails improvement in making use of the public money that it has at its disposal. One of the planes of finance management is management of the budget, that is the annual plan of revenues and expenditure as well as incomes and outgoings, which is adopted for the budget year corresponding to the calendar year. The basis for financial management in the given year is the budget resolution composed of the budget of a local government unit along with the necessary annexes. Revenues and expenditure feature in each budget of a local government unit whereas incomes and outgoings are there for its balance. The incomes in budgets of local government units and revenues alike are forecasts whereas total outgoings identical to expenditure constitute an absolute limit. Budget management concerns the revenue and expenditure aspects as well as formation of short-term and long-term budget equilibrium along with the debt policy of local government units. Budget management is also a wider perception among others from the perspective of the issues related to multiannual budget planning, selection of the sources of financing investments and consequences of the measures taken in this respect (cf. Alińska, Dworakowska, 2015).

Various and multi-aspect influence areas in finance management should be taken into consideration in the analysis of financial standing of local government units. Financial management of local government units is of vital importance as it affects the development of other fields of activity. The most important aspect in functioning of these entities is the state of their finance which is determined by the size of revenues shaping the level of expenditure possible to be incurred. Therefore, it is essential that management of funds be well thought through. Finance is the key element related to functioning of local government units and the primary indicator of the reality and success of each investment. The state of finance is on the one hand shaped by the size of revenues and on the other hand by streaming of expenditure. Revenues and expenditure of local government units are varied as they are caused among others by a various level of the socio-economic development of particular areas of the state. The financial situation of a local government unit is also a source of information on the potential of its economic development.

Financing activities undertaken by local government units is essential. Expenditure incurred by local government units enables fulfilment of collective needs of local and regional communities and its management takes on special importance. The tendencies of the execution of budget expenditure depend on its priorities, which are determined within the catalogue of public tasks assigned to be performed by local government units. These tasks may be of various nature, whether related to investments or not. Execution of budget expenditure first and foremost depends on the amount of obtained budget revenues. With higher funds at disposal in the budget it is easier to allocate money to investments. When commencing an infrastructural undertaking it has to be remembered that money must be ensured for its completion and further use. Carrying out investments by local government units imposes the obligation of securing stable sources of financing them. 


\section{Types of investments in local government units}

Carrying out self-government investments entails expending funds with a view to increasing future tangible and intangible benefits of the self-government community. ${ }^{1}$ The infrastructure created thanks to financial outlays is a public good. Long-term structural effort is necessary in order to decrease disproportions in terms of the primary infrastructure available to residents and it involves conducting investments.

The subject literature distinguishes three primary types of investments, which involve engagement of funds in tangible, financial and intangible assets. The activity of local government units mostly feature tangible investments, whose implementation contributes to the improvement in the condition of the municipal infrastructure. They are divided into the following investments (Michalak, 2007, pp. 21, 23):

1. Multi-task investments - major tangible investments requiring construction and assembly work, usually connected with engagement of a number of entities in their implementation; these are long-term undertakings of high capital intensity whose implementation requires the use of considerable resources and whose completion contributes to following the adopted strategy of the development of a local government unit and constitutes the grounds for socio-economic development of the given area.

2. One-task complex investments - medium investments which are less expensive and require engagement of a smaller number of entities to complete than multi-task investments; they may be implemented by a unit of local government on its own, are of construction or purchase nature and usually entail activities aimed at the exchange or modernisation of the subject of the investment even though their implementation may also slightly increase the scale of the pre-existing activities through creation of new facilities; implementation of these investments may contribute to increasing the residents' satisfaction with the quality of the rendered public services.

3. One-task simple investments - small undertakings, usually performed by an entity on its own; their implementation time is short and they are of purchase nature, usually related to the necessity of renewing old-fashioned or worn out elements of the property; execution of these investments is oriented on a unit of local government ensuring the pre-existing acceptable level of public services rendered for the residents.

Execution of tasks of development and renewal nature requires that substantial financial outlays be incurred, which (Dylewski et al., 2010, p. 120):

- are a serious burden for the budget of a local government unit,

- entail long-term engagement of funds,

${ }^{1}$ Unfortunately, not all investments are well thought through and properly implemented. It is reported more and more frequently that funds are expended on undertakings which from today's perspective seem redundant and generate maintenance costs and outlays to keep the project alive. A selection of badly chosen investments for implementation and their construction are bringing publicity which the self-government authorities would like to avoid. The funds expended on completion of such an undertaking do not close the necessary financial outlays related to them, which often severely affects budgets of the subsequent years in such a local government unit. Badly chosen self-government investments are elaborated in more detail in: Krawiec (2017). 
- will be a source of benefits only in the future,

- are characterised by risk and uncertainty,

- have a considerable influence on achievement of strategic and socially beneficial objectives,

- are strictly connected with the socio-economic development of the given area.

Investments of local government units are often unprofitable, which means that at the moment of planning these undertakings funds necessary for their later maintenance should be taken into consideration, that is the increase in current expenditure on repairs and use of the constructed infrastructural facilities. Investments undertaken by local government units serve the purpose of development of the local social and technical infrastructure and infrastructural investments are their primary type. Investments in the local and regional infrastructure are important for both present and future residents as well as companies. Their implementation improves the living conditions for the residents, attracts companies and prospective inhabitants, who are more willing to settle down or start business operations in developed areas with very convenient access. Establishment of companies results in creating workplaces and development of the unit of local government and this influences the increased satisfaction with the living conditions on the part of the residents. Execution of investments by local government units contributes among others to the local economic development and fulfilment of own tasks and provision of public services. Present investment decisions are the most important factor shaping the future of a unit of local government.

\section{Investment activity in local government units}

Investment activity of local government units is dependent on the state of finance of these entities and the budget analysis serves the purpose of its examination. The specific characteristics of Polish legal regulations referring to local government units enable among others:

- separation of the capital and current budget, which means that the following categories apply: capital revenues, current revenues, capital expenditure and current expenditure,

- analysis of the budget revenues according to the source of origins of proceeds, which results in separation of own revenues ${ }^{2}$ and complementary revenues. ${ }^{3}$

The budget revenues obtained by local government units enable them to implement the budget expenditure. Expenditure of local government units being a part of public expenditure is to satisfy the collective needs of local and regional communities. Expenditure of local government units is implemented directly from their budget or in the form of

\footnotetext{
${ }^{2}$ These should constitute the financial foundation of each unit of local government. They include revenues from taxes and charges, property-related revenues, share in central taxes and other revenues. High own revenues translate into strengthening of the financial basis of local government units.

${ }^{3}$ These supplement own revenues. They involve transfer revenues in the form of general subvention and total subsidies, including targeted subsidies. The key difference between these two types of transfers is that the general subvention is granted based on objective criteria whereas targeted subsidies are granted based on discretionary criteria.
} 
subsidies. Expenditure of the budget of a local government unit is intended among others for execution of various tasks ${ }^{4}$ and programs financed both by means of the funds coming from the budget of the European Union (EU) and non-returnable funds from the assistance granted by the member states of the European Free Trade Association (EFTA) and other funds coming from non-returnable foreign sources.

The budget expenditure of local government units is divided into capital expenditure including (the Act on public finance, i.e. 2016, art. 236 item 2 and 4):

- investments and investment purchases, including programs financed both by means of the funds coming from the budget of the EU and non-returnable funds from the assistance granted by the EFTA member states and other funds coming from non-returnable foreign sources, in the part related to implementation of tasks by local government units,

- purchase and taking up stocks and shares,

- contribution of assets to commercial law companies.

The remaining budget expenditure is treated as current expenditure. It is intended for functioning of local government units and it enables maintenance and use of the pre-existing infrastructure. Current expenditure is much higher than capital expenditure. The latter almost on a whole basis is to finance outlays on investments and is extremely significant. Most of this expenditure depends on the nature of the performed public tasks and financial capacity of a local government unit.

It should be stressed that it was in 2011 that the principle of balancing the budget of a local government unit in its current part was first applied. According to this rule planned current expenditure cannot exceed planned current revenues increased by budget surplus from the previous years and free funds understood as surplus of funds on the current account of the budget of a local government unit, which results from settlements of the issued securities, credits and loans from the previous years. Usually this requirement is also used for the amounts executed at the end of the budget year and any irregularity is possible only in strictly defined cases. This exceptional situation concerns execution of current tasks with the funds from the EU budget and non-returnable funds from the assistance granted by EFTA member states. Then the executed current expenditure may be higher than executed current revenues increased by budget surplus from the previous years and free funds, which is possible only to the amount related to execution of current expenditure regarding the above mentioned funds if this amount was not transferred in the given budget year. The above mentioned changes affected both current expenditure and capital expenditure of local government units.

When making a reference to the structure of total expenditure of local government units in the years 2007-2015 (table 1) it should be emphasised that capital expenditure is especially

\footnotetext{
${ }^{4}$ These include: own tasks, tasks in terms of governmental administration and others allocated by acts of law, taken over for implementation on a contract or agreement basis and executed jointly with other units of local government.
} 
significant as in an overwhelming part it is to finance investment undertakings. The highest share of capital expenditure in total expenditure in voivodships was found in the year 2009 (48.7\%) and these funds were used in particular to execute the development policy of the voivodship. The analysis of particular categories of units of local government reveals that the examined parameter in gminas was highest in 2010 (25.1\%), in cities on powiat status in $2009(23.0 \%)$ and in powiats similarly to gminas in $2010(21.8 \%)$. The highest share of capital expenditure in total expenditure was in voivodships, where every year this percentage was higher than the result of all the units of local government. Taking the same parameter into account the next position was won by cities on powiat status in the years 2007-2008 and 2012-2015 or gminas in the years 2009-2011. In turn, the weakest results on an everyyear basis were achieved by powiats (the worst result coming in the years 2012-2013 at 12.5\%). The higher share of capital expenditure in total expenditure in the given year, the lower share of current expenditure in total expenditure in the same year.

\section{Table 1}

Share of capital expenditure in total expenditure according to the category of local government units in the years 2007-2015 (\%)

\begin{tabular}{llllllllll}
\hline Specification & 2007 & 2008 & 2009 & 2010 & 2011 & 2012 & 2013 & 2014 & 2015 \\
\hline Units of local government in total & 21.0 & 22.0 & 25.7 & 24.9 & 23.4 & 19.7 & 19.0 & 21.0 & 19.6 \\
Gminas & 18.8 & 20.5 & 23.1 & 25.1 & 22.9 & 18.1 & 16.6 & 18.2 & 16.9 \\
Cities on powiat status & 22.5 & 22.7 & 23.0 & 22.3 & 21.2 & 19.9 & 19.1 & 20.9 & 18.5 \\
Powiats & 13.1 & 14.5 & 19.3 & 21.8 & 18.7 & 12.5 & 12.5 & 14.7 & 14.6 \\
Voivodships & 36.7 & 36.7 & 48.7 & 39.0 & 40.5 & 37.8 & 39.7 & 43.0 & 45.1 \\
\hline
\end{tabular}

Shade in the given year the result was higher than the result for local government units in total.

Source: own compilation based on The Reports of the Council of Ministers on the execution of the state budget in the years 2007-2015. Information on the execution of budgets of local government units. Council of Ministers.

The value of share of capital expenditure in total expenditure was substantially influenced by repayable sources of financing (co-financing) investment needs of local government units and non-returnable funds from the EU budget, which with the background of economic crisis mitigated the consequences of economic downturn (cf. Poniatowicz, 2014, pp. 145-154; Strauss-Kahn, 2010). The availability of the Union funds enabled local government units to maintain engagement in the execution of investments although they were afraid of the consequences of the crisis.

\section{Conclusions}

To sum up, the basis for efficient and effective activity of local government units is management and it is finance management which takes on special meaning in their functioning. 
Limited funds require determination of priorities in the area of budget expenditure, which will be consecutively implemented both with reference to one year and multi-year investment undertakings.

Self-government investments affect the size of future revenues and expenditure of local government units. Among self-government investments the prevailing ones are these of tangible nature, which are divided into multi-task or one-task (simple or complex) investments. Execution of investments brings many benefits, among which the key ones are: improvement in the living conditions for residents, improvement in the situation of business entities, attracting people and companies to the given area. Capital expenditure is of considerable importance in budgets of local government units as it enables financing (co-financing) investment activities and thanks to this limiting disproportions in the socio-economic development between regions of the state and shaping further opportunities of such development as well as improving the living conditions. A special importance must be given to the influence of investments on the local and regional development, which is a source of positive changes taking place in the area of local government units.

Execution of investments by local government units is conditioned by the budget capacity of these entities. It is affected by the amounts of revenues and incomes adopted in the budget as well as the amounts of incurred expenditures and outgoings. Possibilities of implementation of capital expenditure are limited first and foremost by the size of necessary current expenditure and the amount obtained from revenues. The higher the share of current expenditure in total expenditure, the lower the share of capital expenditure in total expenditure. Higher current expenditure in comparison with capital expenditure in budgets of local government units indicates their expenditure needs resulting from the scale of the tasks assigned to them to be executed on a current basis. The size of the share of capital expenditure in total expenditure is also affected by repayable sources of financing (co-financing) investment needs of local government units and non-refundable Union funds. In the analysed period the highest share of capital expenditure in total expenditure was observed in voivodships with cities on powiat status or gminas coming next. On the other hand, the lowest share was revealed in powiats. It testifies the scale of engagement of particular categories of local government units in the implementation of investments and enables observation of the consequences of intensity as far as the investment undertakings embarked on by these entities are concerned.

\section{References}

Alińska, A., Dworakowska, M. (2015). Finanse jednostek samorządu terytorialnego. In: A. Alińska, B. Woźniak (eds.), Wspótczesne finanse publiczne (pp. 221-295). Warsaw: Difin.

Dylewski, M., Filipiak, B., Gorzałczyńska-Koczkodaj, M. (2010). Metody analityczne w działalności jednostek podsektora samorzadowego. Warsaw: Difin.

Jastrzębska, M. (2009). Zarządzanie długiem jednostek samorządu terytorialnego. Warsaw: Wolters Kluwer Polska.

Krawiec, S. (2017). Najgłupsze inwestycje w Polsce. Retrieved from: https://www.wprost.pl/tygodnik/10042445/ Najglupsze-inwestycje-w-Polsce.htm (12.03.2017). 
Michalak, A. (2007). Finansowanie inwestycji w teorii i praktyce. Warsaw: Wydawnictwo Naukowe PWN.

Poniatowicz, M. (2014). Wplyw kryzysu gospodarczego na systemy finansowe jednostek samorzadu terytorialnego. Na przykładzie największych miast w Polsce. Warsaw: CeDeWu.

Strauss-Kahn, D. (2010). After the Global Financial Crisis - The Road Ahead for Europe. Retrieved from: http:// www.imf.org/external/np/speeches/2010/032910.htm (12.03.2017).

The Act of 27 August 2009 on public finance, i.e. O.J. 2016, section 1870 with subsequent amendments.

The Reports of the Council of Ministers on the execution of the state budget in the years 2007-2015. Information on the execution of budgets of local government units. Council of Ministers.

\section{AKTYWNOŚĆ INWESTYCYJNA JEDNOSTEK SAMORZĄDU TERYTORIALNEGO W KONTEKŚCIE ZARZĄDZANIA FINANSAMI}

Streszczenie: $\mathrm{Cel}$ - Celem artykułu jest przedstawienie specyfiki zarządzania finansami w jednostkach samorządu terytorialnego w kontekście realizacji inwestycji przez te podmioty. Rozważania są prowadzone z uwzględnieniem analizy aktywności inwestycyjnej jednostek samorządu terytorialnego w Polsce w latach 2007-2015.

Metodologia badania - Ze względu na wieloaspektowy obszar badawczy zastosowano różne metody badawcze, aby osiągnąć wyznaczony cel. W procedurze badawczej użyto metod badań niereaktywnych, wykorzystano metodę analizy dokumentów urzędowych i metodę historyczno-porównawczą.

Wynik - Przeprowadzone analizy wskazują specyfikę aktywności inwestycyjnej realizowanej przez jednostki samorządu terytorialnego i jej szczególną rolę z perspektywy zarządzania finansami tych podmiotów. Zebrane dane świadczą o zaangażowaniu poszczególnych kategorii jednostek samorządu terytorialnego w Polsce w latach 2007-2015 w realizację wydatków majątkowych finansujących inwestycje.

Oryginalność/wartość - Analiza badanego zagadnienia potwierdza, że w jednostkach samorządu terytorialnego duże znaczenie ma zarządzanie finansami. Jest ono szczególnie istotne w kontekście poważnego zaangażowania w realizację inwestycji. Aktywność inwestycyjna jednostek samorządu terytorialnego zależy od sytuacji finansowej tych podmiotów, na którą należy oddziaływać poprzez sprawne i skuteczne zarządzanie. Analiza struktury wydatków budżetowych dokonywanych przez poszczególne kategorie jednostek samorządu terytorialnego w Polsce w latach 2007-2015 umożliwia obserwację zróżnicowania w tym zakresie i stanowi podstawę do oceny przeznaczenia wydatkowanych środków finansowych.

Słowa kluczowe: aktywność inwestycyjna; jednostki samorządu terytorialnego; zarządzanie finansami; wydatki majątkowe

\section{Citation}

Dworakowska, M. (2017). Investment activity of local government units in the context of finance management. Finanse, Rynki Finansowe, Ubezpieczenia, 5 (89/1), 333-341. DOI: 10.18276/frfu.2017.89/1-27. 